\title{
Short communication: Canarium odontophyllum Miq. (dabai) stem bark arrested HCT 116 cell line at $\mathbf{G}_{0} / \mathbf{G}_{1}$ checkpoint
}

\author{
Dayang Fredalina Basri ${ }^{a}$, Ngieng Sheng Ee ${ }^{\mathrm{b}}$, Nor Fadilah Rajab ${ }^{\mathrm{c}}$, Dharrshine Yoganathan ${ }^{\mathrm{b}}$, \\ Raha Ahmad Raus ${ }^{\mathrm{d}^{*}}$ \\ ${ }^{a}$ Centre for Diagnostic, Therapeutic \& Investigative Studies (CODTIS), Faculty of Health Sciences, Universiti Kebangsaan Malaysia, Jalan \\ Raja Muda Abdul Aziz, 50300 Kuala Lumpur, Malaysia \\ ${ }^{b}$ Biomedical Science Programme, Faculty of Heath Sciences, Universiti Kebangsaan Malaysia, Jalan Raja Muda Abdul Aziz, 50300 , \\ Kuala Lumpur, Malaysia \\ ${ }^{\circ}$ Center for Healthy Aging and Wellness (HCARE), Faculty of Allied Health Sciences, Universiti Kebangsaan Malaysia, Jalan Raja \\ Muda Abdul Aziz, 50300, Kuala Lumpur, Malaysia \\ ${ }^{d}$ Department of Biotechnology Engineering, Faculty of Engineering, International Islamic University Malaysia, 50728 Kuala Lumpur, \\ Malaysia
}

Received 27th December 2020 / Accepted 12th May 2021

\begin{abstract}
Canarium odontophyllum Miq. is an exotic plant which is native in Borneo and belong to the Burseraceae family. It contains phytochemicals such as saponin, terpenoid, flavonoid and phenolic compound with potential anticancer property. It has been found that the extract of this plant negatively affected colorectal cancer cells by stimulating apoptosis. To elucidate the apoptosis mechanism induced by the plant extract, this study evaluated the effect of $C$. odontophyllum stem bark acetone extract on cell cycle distribution of HCT 116 cell line using propidium iodide assay. For this purpose, $\mathrm{IC}_{50}$ of the acetone extract of $C$. odontophyllum was first determined by treating HCT 116 cells with the extract for 24, 48 and 72 hours. It was found that the acetone extract of $C$. odontophyllum inhibited proliferation of HCT 116 at $\mathrm{IC}_{50}$ value of $55.09 \pm 18.29 \mu \mathrm{g} / \mathrm{mL}$ for 24 hours treatment, $37.81 \pm 5.09 \mu \mathrm{g} / \mathrm{mL}$ for 48 hours treatment, and $114.9 \pm 16.08 \mu \mathrm{g} / \mathrm{mL}$ following 72 hours treatment. Using IC $_{50}$ value of 48 hours treatment, it was observed that $C$. odontophyllum acetone extract arrested the HCT 116 cells at $G_{0} / G_{1}$ checkpoint. Based on this result, it can be concluded that one of the apoptosis mechanisms induced by C. odontophyllum is by arresting cell cycle of HCT 116 cells at $G_{0} / G_{1}$ checkpoint. This finding warrants further investigation on how $C$. odontophyllum causes the cell cycle arrest and its potential to become anticancer agent.
\end{abstract}

Keywords: apoptosis, Canarium odontophyllum, cell cycle, colorectal cancer, HCT 116

\section{INTRODUCTION}

Colorectal cancer is among the second common cancer worldwide (World health organization, 2018). It is reported as the second common cancer in males and the third common cancer in females in Malaysia (Veettil et al., 2017). Colorectal cancer is commonly treated with surgery for primary disease and chemotherapy for widespread disease (Haraldsdottir et al., 2014). However, chemotherapy is often associated with increased toxicities, adverse effects as well as resistance in cancer cells rendering them unsusceptible to chemotherapy. These prompted scientists to conduct studies to find other compounds for alternative source of anticancer agents (Wong et al., 2019).

*Author for correspondence: Raha Ahmad Raus, Department of Biotechnology Engineering, Faculty of Engineering, International Islamic University Malaysia, 50728 Kuala Lumpur, Malaysia. Email rahaar@iium.edu.my 
Canarium odontophyllum Miq. is an exotic plant of the genus Canarium, family Burseraceae, order Sapindales, class Eudicotyledonae. It is also known as "dabai" and can be found in Sarawak and Sabah, Malaysia and Brunei (Ding, 2011). A previous study found that acetone extract of $C$. odontophyllum stem bark is cytotoxic only towards HCT 116 without exerting cytotoxic effects towards human normal colon cells CCD-18CO (Basri et al., 2016). The extract also induced cell death via apoptosis, indicating that $C$. odontophyllum can be further studied as an anticancer agent against colorectal cancer (Basri et al., 2017).

Cell cycle is a process in which an active living cell divides mitotically before producing two identical daughter cells. In the interphase of cell cycle, cells undergo checkpoints at $G_{0} / G_{1}$ or $\mathrm{G}_{2} / \mathrm{M}$ to ensure the integrity of DNA and that the nutrients are sufficient to go through the next phase in cell cycle until mitosis occurs. Anticancer agent targets cancer cell proliferation by arresting cancer cells at $G_{0} / G_{1}$ or $G_{2} / M$ phase, and arrest at either one of these two phases leads to apoptosis in cancer cells. Basri and Subramaniam (2018) observed that the acetone extract of stem bark of C. odontophyllum causes DNA damage in HCT 116 cells, which can induce apoptosis. Hence, this study aims to evaluate the effect of the extract on the cell cycle distribution in HCT 116 cells.

\section{MATERIALS AND METHODS}

The stem bark of C. odontophyllum was collected from Sarawak and stored in Universiti Kebangsaan Malaysia Herbarium (voucher number: UKMB 40052). Dried acetone extract of stem bark C. odontophyllum was prepared according to Basri and Fan (2005). Stock solution is prepared by suspending dried stem bark acetone extract in 100\% DMSO and mixed using a vortex. Following this, the solution was centrifuged for 5 mins at 20,000 rpm and filtered through a $0.22 \mu \mathrm{M}$ nitrocellulose membrane filter. The stock solution was refrigerated at $-20^{\circ} \mathrm{C}$ prior to treatment with colorectal carcinoma cells. HCT 116 human colorectal carcinoma cell (ATCC® CCL-247TM, Rockville, MD USA) was used in this study and cultured in McCoy's 5A media (Sigma Aldrich, USA) with $10 \%$ fetal bovine serum (FBS) and 1\% penicillin-streptomycin at $37^{\circ} \mathrm{C}$ under $5 \% \mathrm{CO}_{2}$. The cells were cultured to reach $70-80 \%$ confluency approximately 2-3 days before subculture.

To determine the cytotoxicity of $C$. odontophyllum extract towards HCT 116 cells, [3(4,5-dimethyl-2-thiazolyl)-2,5- diphenyl-2Htetrazolium bromide] (MTT) assay (Mosmann, 1983) was carried out were. The cells were seeded in a 96-well plate prior treatment followed by addition with the extract $(12.5-200 \mu \mathrm{g} / \mathrm{mL})$ and menadione as positive control $(0.781-12.50 \mu \mathrm{M})$ for 24,48 and 72 hours, separately. Later, $20 \mu \mathrm{L}$ of MTT $(5 \mathrm{mg} / \mathrm{mL})$ solution was added to each well and incubated for 4 hours. Subsequently, 200 $\mu \mathrm{L}$ of DMSO was added to dissolve the formazon crystals formed, incubated for another $15 \mathrm{~min}$ and shaken on a mixer for $5 \mathrm{~min}$. The absorbance was read at $570 \mathrm{~nm}$ using a microplate reader (BioRad, USA). The viability of cells was calculated using the following formula and half-maximal inhibition concentration $\left(\mathrm{IC}_{50}\right)$ of the extract was extrapolated from graph, cell viability versus extract concentration:

Percentage of viability (\%) $=\frac{\text { Mean Absorbance of Treated Cell }}{\text { Mean Absorbance of Untreated Cell }} \times 100$

Following this, HCT 116 cells with different densities such as $1.5 \times 10^{5}$ cells, $1 \times 10^{6}$ cells, and $5 \times 10^{6}$ cells per well were cultured in 6 -well plates to determine the optimum cell seeding density for cell cycle analysis (Riccardi and Nicoletti, 2006; Jaramillo et al., 2016). Each well was added with complete growth medium to achieve a final volume of $5 \mathrm{~mL}$ and incubated overnight to promote cell attachment. The samples were harvested, fixed in $70 \%$ cold ethanol overnight, and were thoroughly washed with cold PBS (phosphate-buffered saline) to remove ethanol. Staining of samples was carried out using propidium iodide (PI) method by adding PI staining solution $(1 \mathrm{~mL})$ to each sample (Riccardi and Nicoletti, 2006). The samples were transferred to a $5 \mathrm{~mL}$ flow cytometer falcon tube and left to stain in the dark for 1 hour before reading using $\mathrm{BD}$ FACS CANTO II. The protocol was adapted and modified from Moores Cancer Center, UC San Diego Health Sciences (Moores Cancer Center, 2019). 
Based on the optimum experiment above, HCT 116 cells at a density of $5 \times 10^{6}$ cells/well were selected and cultured in a 6-well plate for cell cycle analysis. Each well was added with complete growth medium (McCoy's 5A media with 10\% FBS) to obtain a final volume of $5 \mathrm{~mL}$ and was incubated 24 hours to allow cell attachment. At 24 hours, the exhausted growth medium was changed with a medium containing acetone extract at $\mathrm{IC}_{50}$ value. Positive control of the experiment was carried out by treating the cells with menadione and for negative control, cells were left untreated. Following this, samples were harvested and fixed in $70 \%$ cold ethanol overnight. Samples were thoroughly washed with cold PBS to remove ethanol. After that, staining of samples was carried out by adding PI staining solution to every sample. The samples were left in the dark for an hour to stain after transferring them to a $5 \mathrm{~mL}$ flow cytometer falcon tube before reading using BD FACS CANTO II.

All data obtained were analyzed using GraphPad Prism 6.0 software. Data were processed through one way-ANOVA and two way-ANOVA to compare for significance. All data were carried out in triplicate and shown as mean \pm SEM at $\mathrm{p}<0.05$.

\section{RESULTS AND DISCUSSION}

The cytotoxicity results showed that $C$. odontophyllum acetone extract inhibited HCT 116 with the lowest viability at 48 hours compared to the 24- and 72-hours treatment with the extract (Figure 1). This indicated that the extract requires 48 hours to express its cytotoxicity. However, higher HCT 116 cell viability is recorded after 72 hours treatment compared to 48 hours. This might be due to the instability of certain phytochemicals in the extract. This finding may be explained by Zheng et al. (2016) that reported prolonged exposure of cancer cells at low doses did not inhibit cancer cells' proliferation. In line with this result, plant extract with 48 hours treatment recorded the lowest $\mathrm{IC}_{50}$ value $(37.81 \pm$ $5.09 \mu \mathrm{g} / \mathrm{mL}$ ) while a higher $\mathrm{IC}_{50}$ value of $55.09 \pm$ $18.29 \mu \mathrm{g} / \mathrm{mL}$ and $114.9 \pm 16.08 \mu \mathrm{g} / \mathrm{mL}$ after 24 and 72 hours treatments, respectively (Table 1). This indicated that the extract exhibited its maximum cytotoxic effect at such time point (Efferth et al., 2007). However, the $\mathrm{IC}_{50}$ value obtained in this study is slightly higher than the value obtained by Basri et al. in $2016(25 \pm 5.20$ $\mu \mathrm{g} / \mathrm{mL}$ ) under similar conditions. The difference in $\mathrm{IC}_{50}$ value may be due to storage conditions and period of time that could affect the plant extract's phytochemical content as the stem bark has been stored for more than six months. A study conducted by Dinçer et al. (2013) found the flavonoid compounds and phenolic acids in Salvia tomentosa had decreased after six months of storage. Therefore, a possible decrease in the content of phytochemicals of $C$. odontophyllum stem bark might result in the increase of $\mathrm{IC}_{50}$ value in this study as compared to the $\mathrm{IC}_{50}$ value obtained in Basri et al. (2016). While, $\mathrm{IC}_{50}$ of positive control, menadione was $1.6290 \pm 0.99$ $\mu \mathrm{M}, 0.3479 \pm 0.18 \mu \mathrm{M}$ and $0.4413 \pm 0.21 \mu \mathrm{M}$ after 24 hours, 48 hours and 72 hours treatments, respectively (Table 2, Figure 2).

Optimization of cell seeding density was performed to obtain the optimum number of seeding cells for cell cycle analysis experiment. Seeding densities were selected based on previous studies, i.e., $1.5 \times 10^{5}, 1 \times 10^{6}$, and $5 \times 10^{6}$ cells/well (Riccardi and Nicoletti, 2006; Basri and Subramaniam, 2018). All plates were set to 24 hours to prevent prolonged treatment, causing apoptosis, resulting in the generation of apoptosis peak or "sub-G1" that will influence the percentage of cell cycle distribution. The software ModFit LT 3.2 was used to observe the narrowing of $G_{0} / G_{1}$ and $G_{2} / M$ as the cell seeding density increases. The seeding density with the highest $\mathrm{CV}$ value is $5.340 \pm 0.03 \%\left(1.5 \times 10^{5}\right.$ cells/well $)$, followed by $3.82 \pm 0.47 \%\left(1 \times 10^{6}\right.$ cells $/$ well $)$ and $3.147 \pm 0.12 \%\left(5 \times 10^{6}\right.$ cells/well) (Table 3$)$. There was a significant difference in $\mathrm{CV}$ of $1 \times 10^{6}$ cells/well compared to $\mathrm{CV}$ of $1.5 \times 10^{5}$ cells/well (Figure 3). The CV obtained decreased with an increase in cell seeding density, which indicated the analysis's high accuracy. It was also observed that the histogram background at $1 \times 10^{6}$ cells and $5 \times 10^{6}$ cells is less than at $1.5 \times 10^{5}$ cells. This indicated a reduction in debris, proteins, or cell fragments, and DNA fragments decreased as the $\mathrm{CV}$ increases. A lower CV of 3\% was suggested for cell cycle analysis because a lower CV value yields a narrower $G_{1}$ peak, increasing the accuracy of the cell cycle distribution measured 
(Darzynkiewicz et al., 2017). In this study, the seeding density that is the nearest to the CV of $3 \%$ is $5 \times 10^{6}$ cells/well (CV of $\left.3.147 \pm 0.12 \%\right)$. This suggests a seeding density of $5 \times 10^{6}$ cells/well is the most suitable for cell cycle analysis.

Table 1. $\mathrm{IC}_{50}$ value for extract treatment at three different time points.

Treatment time using acetone extract of $C$. odontophyllum stem bark (hour)

\begin{tabular}{cccc}
$\mathrm{IC}_{50}(\mu \mathrm{g} / \mathrm{mL})$ & $\mathbf{2 4}$ & $\mathbf{4 8}$ & $\mathbf{7 2}$ \\
\cline { 2 - 4 } & $55.09 \pm 18.29$ & $37.81 \pm 5.09$ & $114.9 \pm 16.08$ \\
\hline
\end{tabular}

All data shown are in the form of mean \pm SEM. IC $_{50}$ : Half-maximal inhibitory concentration.

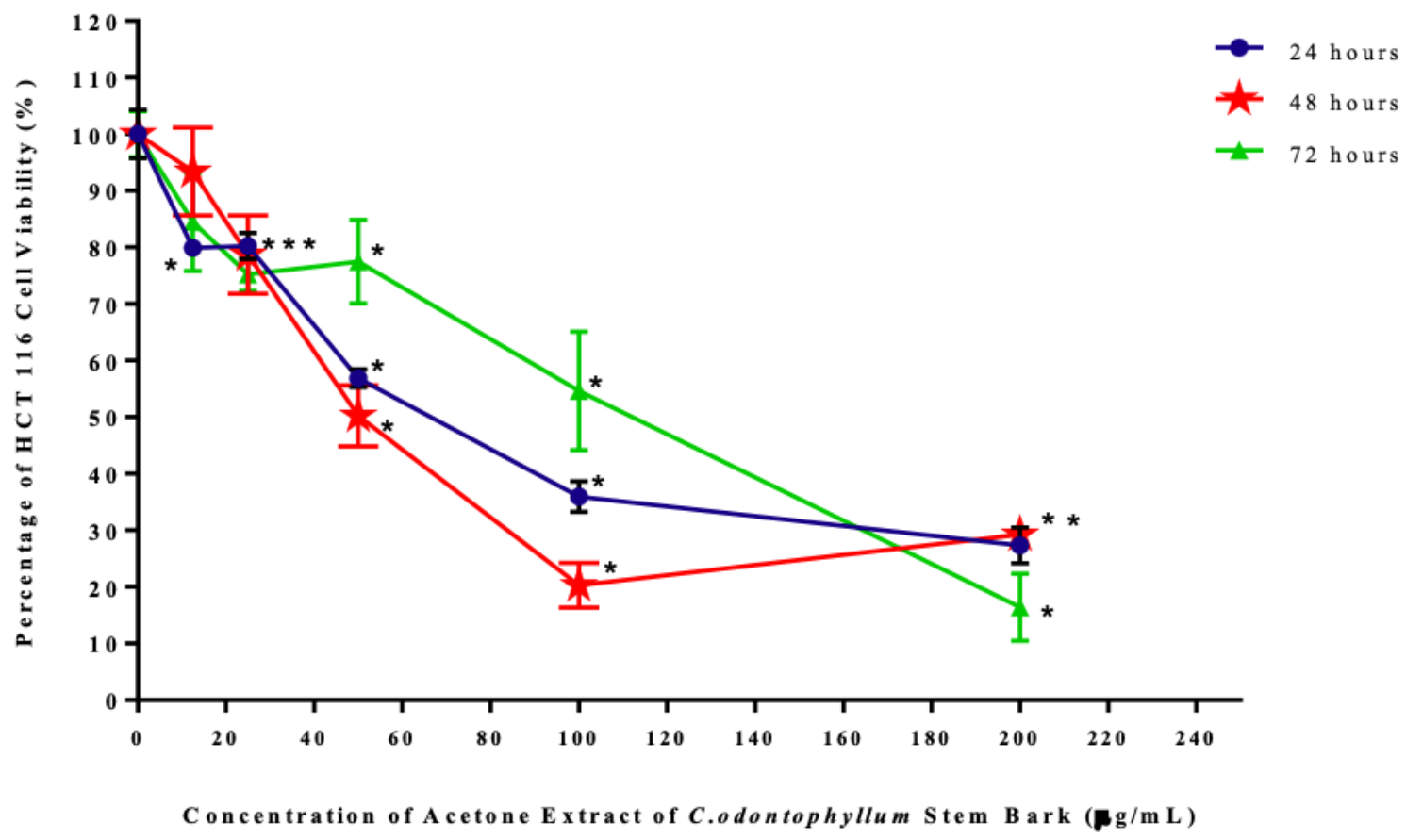

Figure 1. Cytotoxic activity of acetone extract of $C$. odontophyllum stem bark towards HCT 116 at concentration ranging from $0-200 \mu \mathrm{g} / \mathrm{mL}$ after 24,48 , and 72 hours of treatment. All data shown are in the form of mean \pm SEM at significant level $\mathrm{p}<0.05$. $^{{ }^{*} \text { ' }}$ indicates significant difference as compared to untreated cell.

Table 2. $\mathrm{IC}_{50}$ value for menadione treatment at three different time points.

\begin{tabular}{cccc}
\hline & \multicolumn{4}{c}{ Treatment time for Menadione (hour) } \\
\hline \multirow{2}{*}{$\mathrm{IC}_{50}(\mu \mathrm{M})$} & $\mathbf{2 4}$ & $\mathbf{4 8}$ & $\mathbf{7 2}$ \\
\cline { 2 - 4 } & $1.6290 \pm 0.99$ & $0.3479 \pm 0.18$ & $0.4413 \pm 0.10$ \\
\hline
\end{tabular}

All data shown are in the form of mean \pm SEM. IC $_{50}$ : Half-maximal inhibitory concentration. 


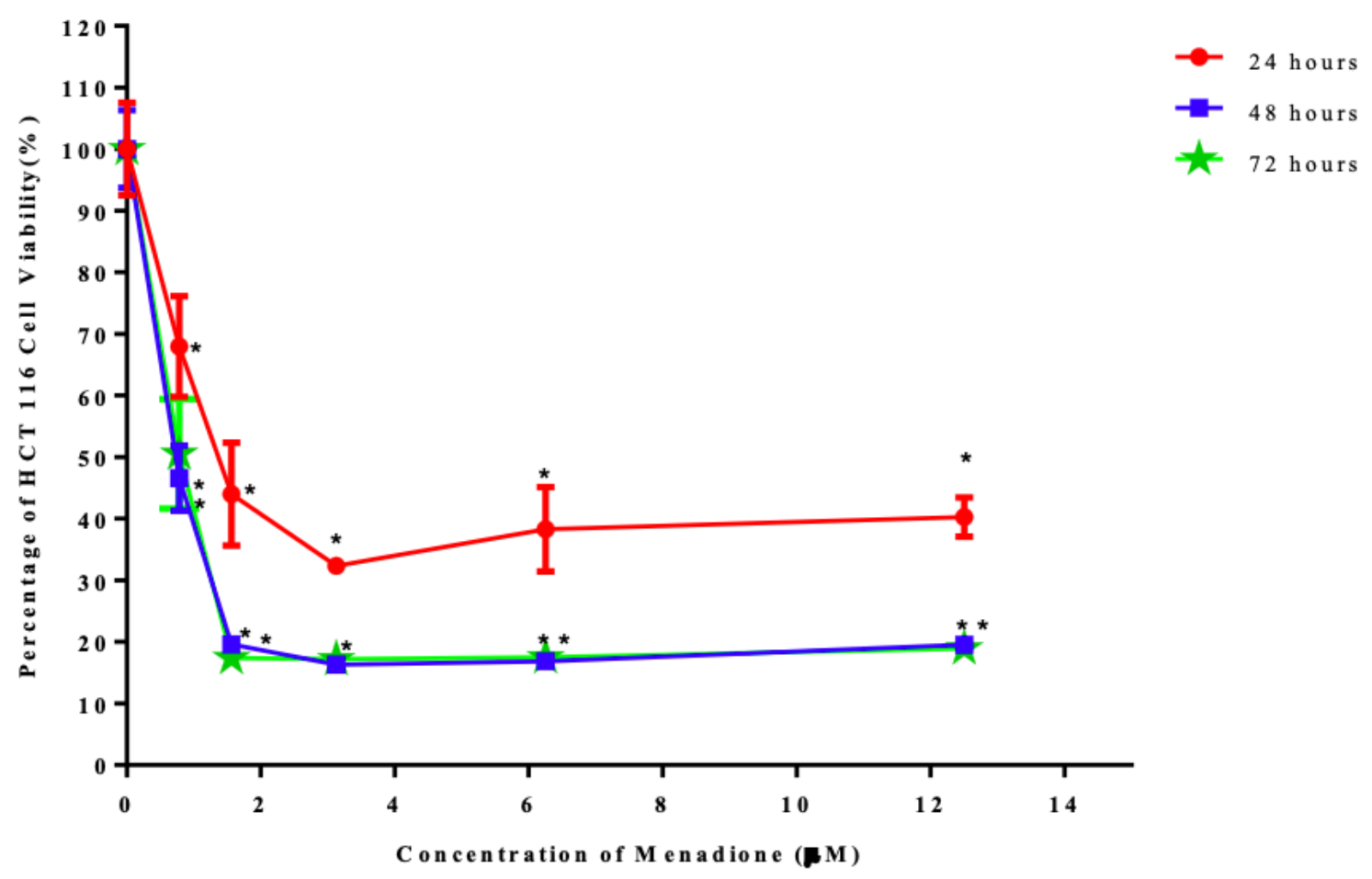

Figure 2. Cytotoxic activity of menadione against HCT 116 at concentration ranging from $0-12.5 \mu \mathrm{M}$ after 24,48 , and 72 hours of treatment. All data shown are in the form of mean \pm SEM at significant level $\mathrm{p}<0.05$. ' $*$ ' indicates significant difference as compared to untreated cell.

Table 3. Cell seeding density for each well with mean percentage of Coefficient of $V$ ariance.

\begin{tabular}{ccccc}
\hline $\begin{array}{c}\text { Cell Seeding } \\
\text { Density } \\
\text { (cells/well) }\end{array}$ & $\begin{array}{c}\text { Percentage of Mean } \\
\text { of Coefficient of } \\
\text { Variance, CV (\%) }\end{array}$ & $\begin{array}{c}\text { Standard Error } \\
\text { Mean, SEM (\%) }\end{array}$ & $\begin{array}{c}\text { Total events } \\
\text { achievable (evts) }\end{array}$ & N \\
\hline $1.5 \times 10^{5}$ cells & $5.340 \pm 0.03$ & 0.03 & 10000 & 3 \\
$1 \times 10^{6}$ cells & $3.823 \pm 0.47$ & 0.47 & 20000 & 3 \\
$5 \times 10^{6}$ cells & $3.147 \pm 0.12$ & 0.117 & 20000 & 3 \\
\hline
\end{tabular}

All data shown are in the form of mean \pm SEM.

For a more accurate cell cycle analysis, 20,000 events count (evts) was suggested in the cell cycle study by Shen et al. (2017). From all the three densities used in this study, only seeding densities of $1 \times 10^{6}$ and $5 \times 10^{6}$ cells /well were able to achieve 20,000 evts, whereas $1.5 \times 10^{5}$ cells/well could collect up to 10,000 evts (Table 3). The different total number of evts observed in this study is because cell seeding density affects cell growth. Ghosh et al. (2010) demonstrated a higher cell seeding density increases protein expression and elevates adipose stromal cells' proliferation by the increase in contact point between cells. As HCT 116 cells are adherent cells, high seeding density ensures close contact point with surrounding cells, enhancing cell proliferation. Less cell seeding density than optimum will reduce close contact that eventually affects cells' growth and influence the number of events achievable for cell cycle analysis. Cell seeding density lower than optimum also influences the kinetics of cancer cells as the efficacy of anticancer agents is controlled by the rate of cell proliferation, enzymatic activity, and the microenvironment (Kelmer and Wilson, 2007; Vadlapatla et al., 2013; Gu and Mooney, 2015). The affected kinetics of cancer cells will influence the cytotoxicity, efficacy, and outcome of cell cycle arrest when treated with the anticancer agent of interest. Based on both the CV value and the evts recorded by each seeding density, $5 \times 10^{6}$ 
cells/well was used in the cell cycle analysis experiment.

In the cell cycle analysis, the percentage of cell distribution in cell cycle phases depicted a significant increase $(\mathrm{p}<0.05)$ of HCT 116 cells at G0/G1 phase $(75.99 \pm 0.63 \%)$ compared to negative control (65.92 $\pm 2.63 \%$ ) (Table 4, Figure 4) after the cells were subjected to the $C$. odontophyllum acetone extract $\mathrm{IC}_{50}$ at 48 hours, $37.81 \pm 5.09 \mu \mathrm{g} / \mathrm{mL}$ ) indicating there was an arrest at cell cycle checkpoint $G_{0} / G_{1}$. Previously, cell cycle arrest at checkpoint $G_{0} / G_{1}$ has been shown to stimulate apoptosis (Chen et al., 2010; Zorofchian et al., 2014). It is possible that the cell cycle arrest at $\mathrm{G}_{0} / \mathrm{G}_{1}$ induced by the acetone extract of $C$. odontophyllum also leads to apoptosis as previously demonstrated by Basri et al. (2016) in which the extract caused apoptosis in HCT cells. It is noted that there was an increase observed in the $\mathrm{G}_{0} / \mathrm{G}_{1}$ phase of menadione-treated HCT 116 cells $(73.19 \pm 12.71 \%)$ in comparison to untreated cells. This showed that cell cycle of menadionetreated HCT 116 cells was arrested at $G_{0} / G_{1}$ checkpoint although the effect of menadione is somewhat weak as the increase was not significant. In spite of this, the ability of menadione to arrest cancer cells is reported by Lee et al. (2016) which demonstrated that menadione induced apoptosis in prostate cancer and caused $\mathrm{G}_{0} / \mathrm{G}_{1}$ checkpoint arrest. Various studies also stated that menadione was cytotoxic and induced $\mathrm{G}_{1}$ arrest towards cancer cells (Hitomi et al., 2005; Klaus et al., 2010).

The ability of the $C$. odontophyllum stem bark acetone extract to arrest the cell cycle at $G_{0} / G_{1}$ in this study exhibits the potential of this extract to regulate the modulators in cell cycle, such as the protein cyclin-dependent kinases (CDKs). CDK primarily reduces the level of protein cyclins such as cyclin D-1 that arrest cells at $G_{0} / G_{1}$ phase (Klaus et al., 2010). The importance of acetone extract of C. odontophyllum in arresting HCT 116 at $\mathrm{G}_{0} / \mathrm{G}_{1}$ marked a point of interest for further study of molecular mechanism of cell cycle affected by the extract. Whether C. odontophyllum extract affects modulators such as cyclin D and $\mathrm{E}$ as well as CDK2, CDK4, and CDK6 that are involved in promoting DNA replication phase and cell division through regulation of $G_{0} / G_{1}$ phase is not known and warrants further investigation (Song et al., 2017).

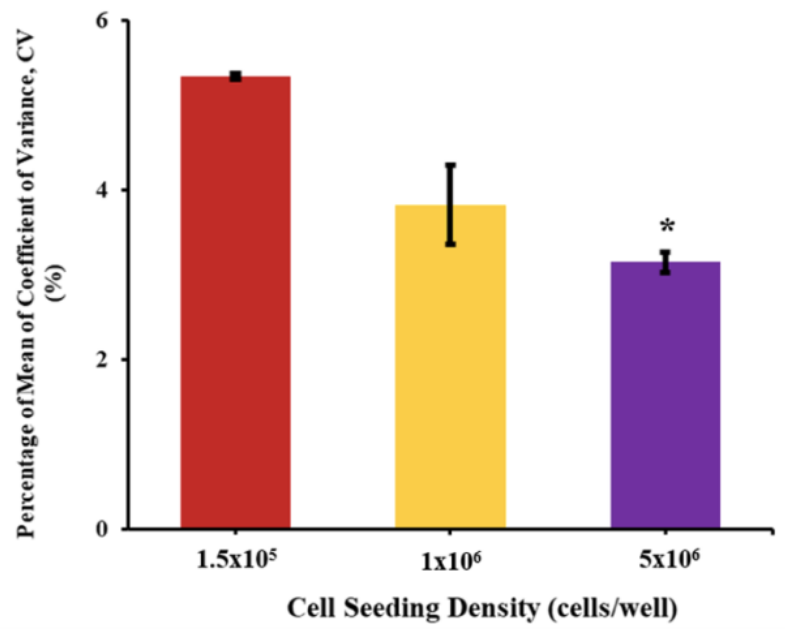

Figure 3. Graph comparison of Coefficient of Variance between different cell seeding densities. All data shown are in the form of mean \pm SEM at significant level $\mathrm{p}<0.05$. ' $*$ ' indicates significant difference as compared to control $1.5 \times 10^{5}$ cells $(\mathrm{p}<0.05)$.

Table 4. Percentage of cell cycle distribution for three different treatment groups.

\begin{tabular}{cccc}
\hline & \multicolumn{3}{c}{ Mean of percentage of cell in phases (\%) } \\
\cline { 2 - 4 } Cell cycle phase & $\begin{array}{c}\text { Control } \\
\text { IC }_{50} \text { of acetone } \\
\text { extract of } \boldsymbol{C} . \\
\text { (Untreated cell) }\end{array}$ & $\begin{array}{c}\text { odontophyllum stem } \\
\text { bark treated }\end{array}$ & IC $_{50}$ Menadione \\
\hline $\mathrm{G}_{0} / \mathrm{G}_{1}$ & $65.92 \pm 2.63$ & $75.99 \pm 0.63$ & $73.19 \pm 12.71$ \\
$\mathrm{~S}$ & $28.25 \pm 0.84$ & $18.51 \pm 0.48$ & $20.76 \pm 9.75$ \\
$\mathrm{G}_{2} / \mathrm{M}$ & $5.84 \pm 2.12$ & $5.50 \pm 0.28$ & $6.04 \pm 2.96$ \\
\hline
\end{tabular}

All data shown are in the form of mean \pm SEM. IC $_{50}$ : Half-maximal inhibitory concentration. 


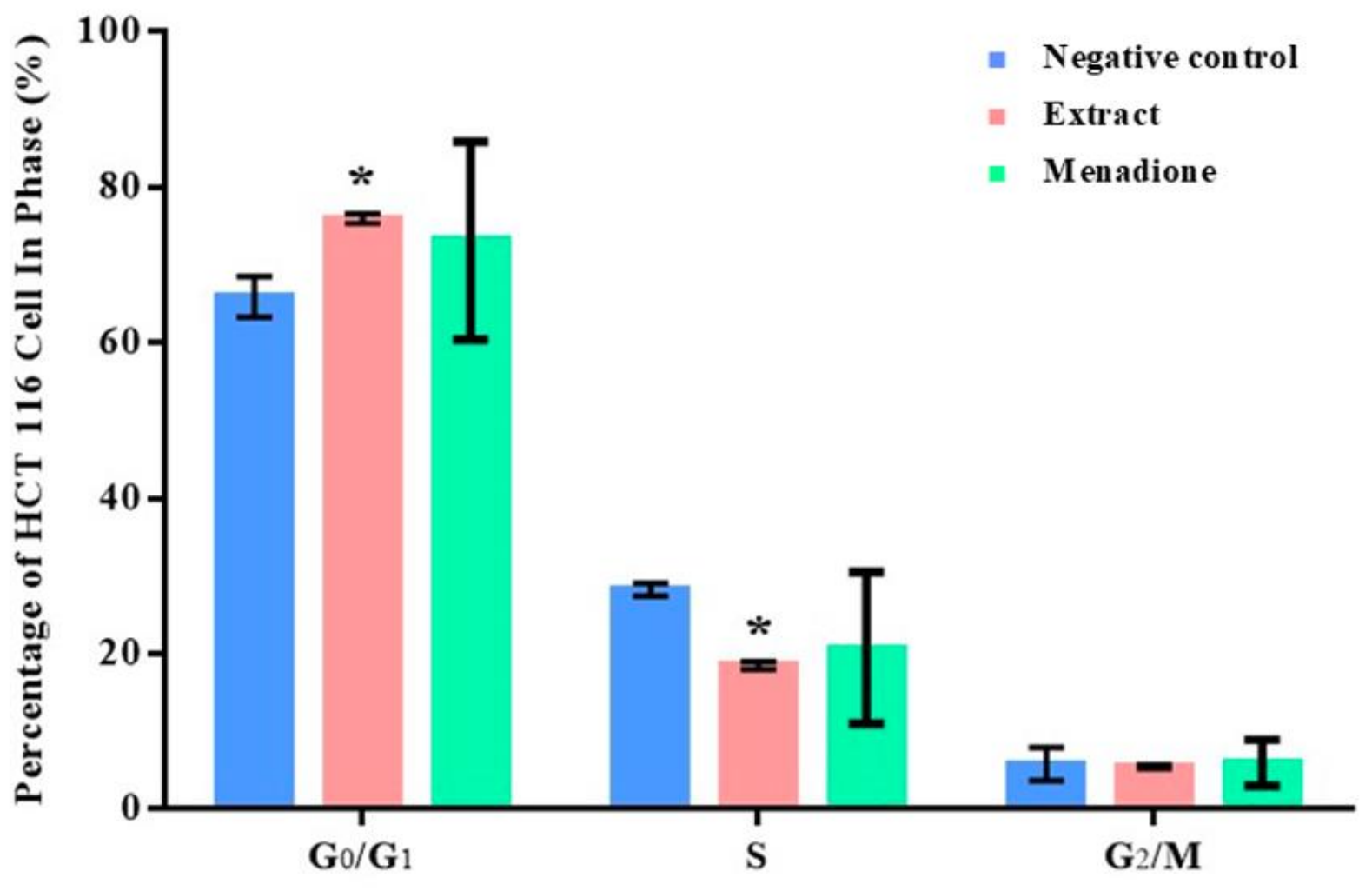

Phases of Cell Cycle

Figure 4. Comparison between percentages of cell distribution at different cell seeding densities in negative control (untreated cells) and cells treated with $\mathrm{IC}_{50}$ of extract $(37.81 \pm 5.09 \mu \mathrm{g} / \mathrm{mL}$ when treated for 48 hours) and $\mathrm{IC}_{50}$ of menadione $(0.3479 \pm 0.18 \mu \mathrm{M}$ when treated for 48 hours). All data shown are in the form of mean \pm SEM at significant value $\mathrm{p}<0.05$. ' $*$ ' indicates significant difference as compared to untreated cell.

\section{CONCLUSION}

C. odontophyllum Miq. stem bark acetone extract was cytotoxic towards HCT 116 cells at $\mathrm{IC}_{50}$ value of $37.81 \pm 5.09 \mu \mathrm{g} / \mathrm{mL}$ when treated for 48 hours. At cell seeding density of $5 \times 10^{6}$ cells/well and treatment with the $\mathrm{IC}_{50}$ of $C$. odontophyllum acetone extract for 24 hours, cell cycle of HCT 116 cells were arrested at $G_{0} / G_{1}$ checkpoint. Hence, $C$. odontophyllum stem bark can be further explored as an anticancer agent against colorectal cancer.

\section{ACKNOWLEDGEMENTS}

The colorectal cell line used in this study was kindly provided Prof. Madya. Dr. Saiful Anuar
Karsani from Institute of Biological Sciences, Universiti Malaya. This project was supported by the research code grant Research University Grant GUP-2016-036.

\section{CONFLICT OF INTERESTS}

The authors have declared that no conflict of interest exists.

\section{REFERENCES}

Basri, D. F., \& Fan, S. H. 2005. The potential of aqueous and acetone extracts of galls of Quercus infectoria as antibacterial agents. Indian Journal of Pharmacology 37(1): 26-29.

Basri, D. F., \& Subramaniam, S. 2018. Effect of Canarium odontophyllum stem bark extract against human colorectal 
cancer cell line HCT 116. International Journal of Medical Research and Pharmaceutical Sciences 5(9): 10-18.

Basri, D. F., Alamin, Z. A. Z., \& Chan, K. M. 2016. Assessment of cytotoxicity and genotoxicity of stem bark extracts from Canarium odontophyllum Miq. (dabai) against HCT 116 human colorectal cancer cell line. BMC Complementary and Alternative Medicine 16(1): 36.

Basri, D. F., Awang -Hasan, W. U. N., Alamin, Z. A. Z., \& Chan, K. M. 2017. Mechanism of cytotoxic activity of Canarium odontophyllum Miq. (dabai) against human colon cancer cell line HCT 116. Journal of Chemical and Pharmaceutical Science 10: 109-115.

Chen, H. L., Lin, K. W., Huang, A. M., Tu, H. Y., Wei, B. L., Hour, T. C., Yen, M. H., Pu, Y. S., \& Lin, C. N. 2010. Terpenoids induce cell cycle arrest and apoptosis from the stems of Celastrus kusanoi associated with reactive oxygen species. Journal of Agricultural and Food Chemistry 58(6): 3808-3812.

Darzynkiewicz, Z., Huang, X., \& Zhao, H. 2017. Analysis of cellular DNA content by flow cytometry. Current Protocols in Cytometry 82: 7.5.1-7.5.20.

Dinçer, C., Tontul, İ., Çam, İ. B., Özdemir, K. S., Topuz, A., ŞahinNadeem, H., Tugrul, Ay. S., \& Göktürk, R. S. 2013. Phenolic composition and antioxidant activity of Salvia tomentosa Miller: Effects of cultivation, harvesting year, and storage. Turkish Journal of Agriculture and Forestry 37(5): 561567.

Ding, P. 2011. Dabai (Canarium odontophyllum Miq.). Postharvest Biology and Technology of Tropical and Subtropical Fruits: 34-42e.

Efferth, T., Fu, Y. J., Zu, Y. G., Schwarz, G., Konkimalla, V. S. B., \& Wink, M. 2007. Molecular target-guided tumor therapy with natural products derived from traditional chinese medicine. Current Medicinal Chemistry 14(9): 2024-2032.

Ghosh, S., Dean, A., Walter, M., Bao, Y., Hu, Y., Ruan, J., \& Li, R. 2010. Cell density-dependent transcriptional activation of endocrine-related genes in human adipose tissue-derived stem cells. Experimental Cell Research 316(13): 2087-2098.

Gu, L. \& Mooney, D. J. 2015. Biomaterials and emerging anticancer therapeutics: Engineering the microenvironment. Nature Reviews Cancer 16(1): 56-66.

Haraldsdottir, S., Einarsdottir, H. M., Smaradottir, A., Gunnlaugsson, A., \& Halfdanarson, T. R. 2014. Colorectal cancer - review. Laeknabladid 100(2): 75-82.

Hitomi, M., Yokoyama, F., Kita, Y., Nonomura, T., Masaki, T., Yoshiji, H., Inoue, H., Kinekawa, F., Kurokohchi, K., \& Uchida, N. 2005. Antitumor effects of vitamins K1, K2 and $\mathrm{K} 3$ on hepatocellular carcinoma in vitro and in vivo. International Journal of Oncology 26(3): 713-720.

Jaramillo, S., Muriana, F. J., Guillen, R., Jimenez-Araujo, A., Rodriguez-Arcos, R., \& Lopez, S. 2016. Saponins from edible spears of wild asparagus inhibit Akt, P70s6k, and Erk signalling, and induce apoptosis through $\mathrm{G}_{0} / \mathrm{G}_{1}$ cell cycle arrest in human colon cancer HCT-116 cells. Journal of Functional Foods 26: 1-10.

Kelmer, G., \& Wilson, D. A. 2007. Bilateral metatarsophalangeal arthrodesis for severe congenital flexor tendon laxity and metatarsophalangeal luxation in a miniature horse. Equine Veterinary Education 19(10): 547-550.

Klaus, V., Hartmann, T., Gambini, J., Graf, P., Stahl, W., Hartwig, A., \& Klotz, L. O. 2010. 1,4-naphthoquinones as inducers of oxidative damage and stress signaling in $\mathrm{HaCaT}$ ignaling in hacat human keratinocytes. Archives of Biochemistry and Biophysics 496(2): 93-100.

Lee, M. H., Yang, J. Y., Cho, Y., Park, M., Woo, H. J., Kim, H. W., Kwon, H. J., Kim, S. H., Moon, C., \& Kim, T. U. 2016. Menadione induces apoptosis in a gastric cancer cell line mediated by down-regulation of X-linked inhibitor of apoptosis. International Journal of Clinical and Experimental Medicine 9(2): 2437-2443.
Moghadamtousi, S. Z., Karimian, H., Rouhollahi, E., Paydar, M., Fadaeinasab, M., Abdul \& Kadir, H. A. 2014. Annona muricata leaves induce G1 cell cycle arrest and apoptosis through mitochondria-mediated pathway in human HCT116 and HT-29 colon cancer cells. Journal of Ethnopharmacology 156: 277-289.

Moores Cancer Center. 2019. Cell cycle analysis by DNA content (Propidium iodide). San Diego: University of California.

Mosmann, T. 1983. Rapid colorimetric assay for cellular growth and survival: Application to proliferation and cytotoxicity assays. Journal of Immunological Methods 65(1-2): 55-63.

Riccardi, C., \& Nicoletti, I. 2006. Analysis of apoptosis by propidium iodide staining and flow cytometry. Nature Protocols 1(3): 1458-1461.

Shen, Y., Vignali, P., \& Wang, R. 2017. Rapid profiling cell cycle by flow cytometry using concurrent staining of DNA and mitotic markers. Bio-protocol 7(16): e2517.

Song, X. L., Zhang, Y. J., Wang, X. F., Zhang, W. J., Wang, Z., Zhang, F., Zhang, Y. J., Lu, J. H., Mei, J. W., Hu, Y. P., Chen, L., Li, H. F., Ye, Y. Y., Liu, Y. B., \& Gu, J. 2017. Casticin induces apoptosis and $\mathrm{G}_{0} / \mathrm{G}_{1}$ cell cycle arrest in gallbladder cancer cells. Cancer Cell International 17: 9.

Vadlapatla, R., Vadlapudi, A., Pal, D., \& Mitra, A. 2013. Mechanisms of drug resistance in can- cer chemotherapy: Coordinated role and regulation of efflux transporters and metabolizing enzymes. Current Pharmaceutical Design 19(40): 7126-7140.

Veettil, S. K., Lim, K. G., Chaiyakunapruk, N., Ching, S. M., \& Abu Hassan, M. R. A. 2017. Colorectal cancer in Malaysia: Its burden and implications for a multiethnic country. Asian Journal of Surgery 40(6): 481-489.

Wong, K. E., Ngai, S. C., Chan, K. G., Lee, L. H., Goh, B. H., \& Chuah, L. H. 2019. Curcumin nanoformulations for colorectal cancer: A review. Frontiers in Pharmacology 10: 152.

World health organization. 2018. Latest global cancer data: cCancer burden rises to 18.1 million new cases and 9.6 million cancer deaths in 2018. Geneva: World health organization.

Zheng, X. H., Nie, X., Liu, H. Y., Fang, Y. M., Zhao, Y., \& Xia, L. X. 2016. Tmpyp4 promotes cancer cell migration at low doses, but induces cell death at high doses. Scientific Reports 6(1): 26592. 